\title{
scripted
}

Volume 10, Issue 4, December 2013

\section{SCRIPTED: NEWS AND REFLECTION}

Aisling McMahon* \& Laura Downey*

DOI: $10.2966 /$ scrip.100413.409

\section{(9) $\odot \Theta \Theta$}

(C) Aisling McMahon, Laura Downey 2013. This work is licensed under a Creative Commons Attribution-NonCommercial-ShareAlike 4.0 International License. Please click on the link to read the terms and conditions.

* Editor-in-Chief, SCRIPTed. PhD Candidate in Law, University of Edinburgh.

${ }^{*}$ Managing Editor, SCRIPTed. PhD Candidate in Law, University of Edinburgh. 
This issue marks the final issue of the tenth volume of SCRIPTed, and with the tenth anniversary approaching, we would like to take this opportunity to briefly reflect on the journal.

\section{Reflections on SCRIPTed - looking back on ten volumes}

Over the last ten volumes, we are very proud to report that SCRIPTed has published 35 issues containing 39 editorials, 155 articles, 72 analysis pieces, 30 reports and 94 book reviews; not including the content in this issue. Alongside this SCRIPTed has published a number of special features ranging from the transcripts of keynote lectures to a special section on Zombies. Our website has been visited by tens of thousands of readers from across the globe whose continued support and readership make SCRIPTed possible and worthwhile. To you, our readers, we would like to extend our heartfelt thanks and appreciation.

We would also like to take this opportunity to extend our gratitude to our funders over the years and our management team, advisory board and voluntary editors, both past and present, without whose assistance and dedication SCRIPTed could not have enjoyed the success it has.

\section{Foresighting SCRIPTed - Looking to the future}

SCRIPTed has always sought and continues to seek to contribute to discussions surrounding the relationship between law, ethics, policy and new technologies. Past submissions have employed interesting and novel approaches to investigate the myriad of challenges presented to our laws by new technologies. It is hoped that the next issues will offer similarly diverse and innovative contributions as has been seen over the past ten volumes. In this vein, we would like to remind all that we welcome submissions of a legal and interdisciplinary nature relating to the interaction of new technologies and law.

\section{News from SCRIPTed}

The editorial board has seen some changes this year, with our Editor-in-Chief Nayha Seithi stepping down and Aisling McMahon, our former Managing Editor, taking over this role. We also welcome Laura Downey to the position of Managing Editor. Our Technical Editor Andres Guadamuz, who has been involved with the journal since its inception, will also be stepping down and SCRIPTed will be welcoming Laurence Diver to this role. Andres will however be staying on in an advisory capacity. And finally, we are saying goodbye to Daithí MacSíthigh, our Supervising Editor for IT, and welcoming Nicolas Jondet to this position.

We hope you enjoy this issue and continue to enjoy future issues of SCRIPTed. From everyone at SCRIPTed Happy Holidays! 